\title{
HEMITRICHIA SERPULA VAR. PIAUIENSIS (TRICHIACEAE, MYXOMYCETES) - A NEW VARIETY FROM BRAZIL
}

\author{
Laise de Holanda Cavalcanti ${ }^{1}$ \\ Mitra Mobin²
}

Recebido em 8/8/2000. Aceito em 11/9/2000

\begin{abstract}
RESUMO - (Hemitrichia serpula var. piauiensis (Trichiaceae, Myxomycetes) - uma nova variedade do Brasil). Uma nova variedade de Hemitrichia serpula (Scop.) Rost. do Brasil, Hemitrichia serpula var. piauiensis Cavalcanti \& Mobin é descrita e ilustrada. O novo táxon tem um capilício menos espinuloso, com espinhos curtos e esparsos; os esporos são delicadamente reticulados, com malhas bem definidas. O tipo está depositado no Herbário UFP, Coleção de Myxomycetes, Universidade Federal de Pernambuco (Recife, Estado de Pernambuco, Brasil). É apresentada também uma chave de identificação para as três variedades da espécie.
\end{abstract}

Palavras-chave - Myxomycetes, Trichiaceae, Hemitrichia, Arecaceae

\begin{abstract}
Hemitrichia serpula var. piauiensis (Trichiaceae, Myxomycetes) - A new variety from Brazil). A new variety of Hemitrichia serpula (Scop.) Rost. from Brazil, H. serpula var. piauiensis Cavalcanti \& Mobin, is described and illustrated. The new taxon has a somewhat less spinulose capillitium, with short and scattered spines; spores are finely reticulate, with well-defined meshes. The type is deposited in the Herbarium UFP, Myxomycete Collection, Federal University of Pernambuco (Recife, Pernambuco State, Brazil). A key to the three varieties of the species is presented as well.
\end{abstract}

Key words - Myxomycetes, Trichiaceae, Hemitrichia, Arecaceae

\section{Introduction}

Dead palm leaves and bark are good substrates for a number of Myxomycetes species (Pôrto et al. 1985; Villaró 1991; Alves \& Cavalcanti 1996). Among them is Hemitrichia serpula (Scop.) Rost. (Trichiaceae), a cosmopolitan species characterized by its golden yellow plasmodiocarps, spinulose capillitium and banded-reticulate spores. A new variety, H. serpula var. tubiglabra Nann.-Brem. \& Yam. has been published recently by NannengaBremekamp \& Yamamoto (1990) from Nepal, collected on dead, mossy wood. This new variety has somewhat more robust capillitium

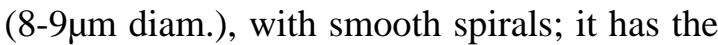

\footnotetext{
1 Departamento de Botânica, CCB, Universidade Federal de Pernambuco, Av. Prof. Moraes Rego s/n, CEP 50670-901, Recife, PE, Brasil, e-mail: lhc@ netpe.com.br

2 Departamento de Biologia, CCN, Universidade Federal do Piauí, Campus da Ininga, CEP 64049-550, Teresina, PI, Brasil, mitra@etfpi.g12.br
} 
typical spore reticulation, with about 4-5 meshes across the diameter.

Plasmodiocarps of $H$. serpula with reticulated spores and capillitium bearing long spines were collected in Piauí State, Northeastern Brazil. Among several specimens which fruited on palm trees, recently collected in this State, seven proved to be a new variety of this species. It is described and illustrated in this paper.

\section{Material and methods}

Frutifications were colected on dead leaves of two Arecaceae species: Astrocaryum vulgare Mart. (tucum) and Mauritia flexuosa L.f. (buriti), during the rainy season (December and January), in the Sete Cidades National Park ( $4^{\circ} 5^{\prime}-4^{\circ} 15^{\prime} \mathrm{S}$, $41^{\circ} 30^{\prime}-41^{\circ} 40^{\prime} \mathrm{W}, 180 \mathrm{~m}$ elev.), Piripiri County, state of Piauí, Brazil. The samples were collected from two different areas, in a secondary tropical forest (Piscina do Bacuri) and in a Brazilian savanna (Abrigo do Parque). Traditional herbarium methods were used in collecting and dehydrating specimens (Farr 1976).

The material was observed through the light microscope (LM) under oil immersion objective (Teixeira 1971), and with the scanning electron microscope (SEM). Fructifications were prepared for scanning electron microscopy as follows: capillitium and spores were placed on double adhesive cellophane tape mounted on a specimen stub, sputter-coated with gold (Fine coat sputter JFC-1100), and examined in a JEOL-JSM- T200 Stereoscan (Nelson et al. 1982).

The nomenclature followed in this paper is that of Martin et al. (1983) and Martin \& Alexopoulos (1969).

\section{Results and discussion}

Hemitrichia serpula var. piauiensis Cavalcanti \& Mobin, n. var.

A varietate serpula sporae delicate reticulatus et capilitium cum curta et sparsa aculis differt.

Plasmodiocarps branched, reticulate, orange yellow, shining. Hypothallus membranous, dark brown. Peridium single, membranous, persistent, yellow by transmitted light. Capillitium tubular, elastic, golden yellow; capillitial threads branched, with short, scattered spines and spiral bands connected by longitudinal striae, 4.5-6.0 $(-8.0) \mu \mathrm{m}$ diam. Spores subglobose, golden yellow in mass, yellow under transmitted light, verrucose or warty-reticulate, 10.5-12.0 $(-13.8) \mu \mathrm{m}$ diam.

Type: Brasil: Piaur: Piripiri, Parque Nacional de Sete Cidades, Piscina do Bacuri, 26/VI/1995, on dead leaves of Mauritia flexuosa L. f., M. Mobin 280 (UFP16386), (Holotypus UFP, Isotypus TEPB).

Paratypes: Brasil: Piauí: Piripiri, Parque Nacional de Sete Cidades, Piscina do Bacuri, 26/VI/1995, on dead leaves of. Astrocaryum vulgare Mart., Mitra Mobin 182 (UFP 16280); 26/VI/1995, on dead leaves of Mauritia flexuosa L. f., Mitra Mobin 265 (UFP 16405).

The yellow plasmodiocarp of Hemitrichia serpula var. piauiensis is macroscopically similar to those of var. serpula or var. tubiglabra, but the specimens described in this paper differ from those varieties in the ornamentation of spores and capillitium. As observed in the light microscope, the capillitia of both var. serpula and var. piauiensis show spiral thickenings and spines connected by small ridges parallel with the length of the threads. However, the threads of var. serpula are more densely spinulose, with long and slender spines, while those of var. piauiensis have scattered, shorter spines (Fig. 1-4). The capillitial threads of var. tubiglabra, by contrast, are distintive in their thickness (8.09.0 $\mathrm{mm}$ diam.) and smooth spirals (Fig. 5-6). On both types of threads, the spiral thickenings and spines are connected by small ridges parallel with the length of the threads.

The spores of var. piauiensis differ from 


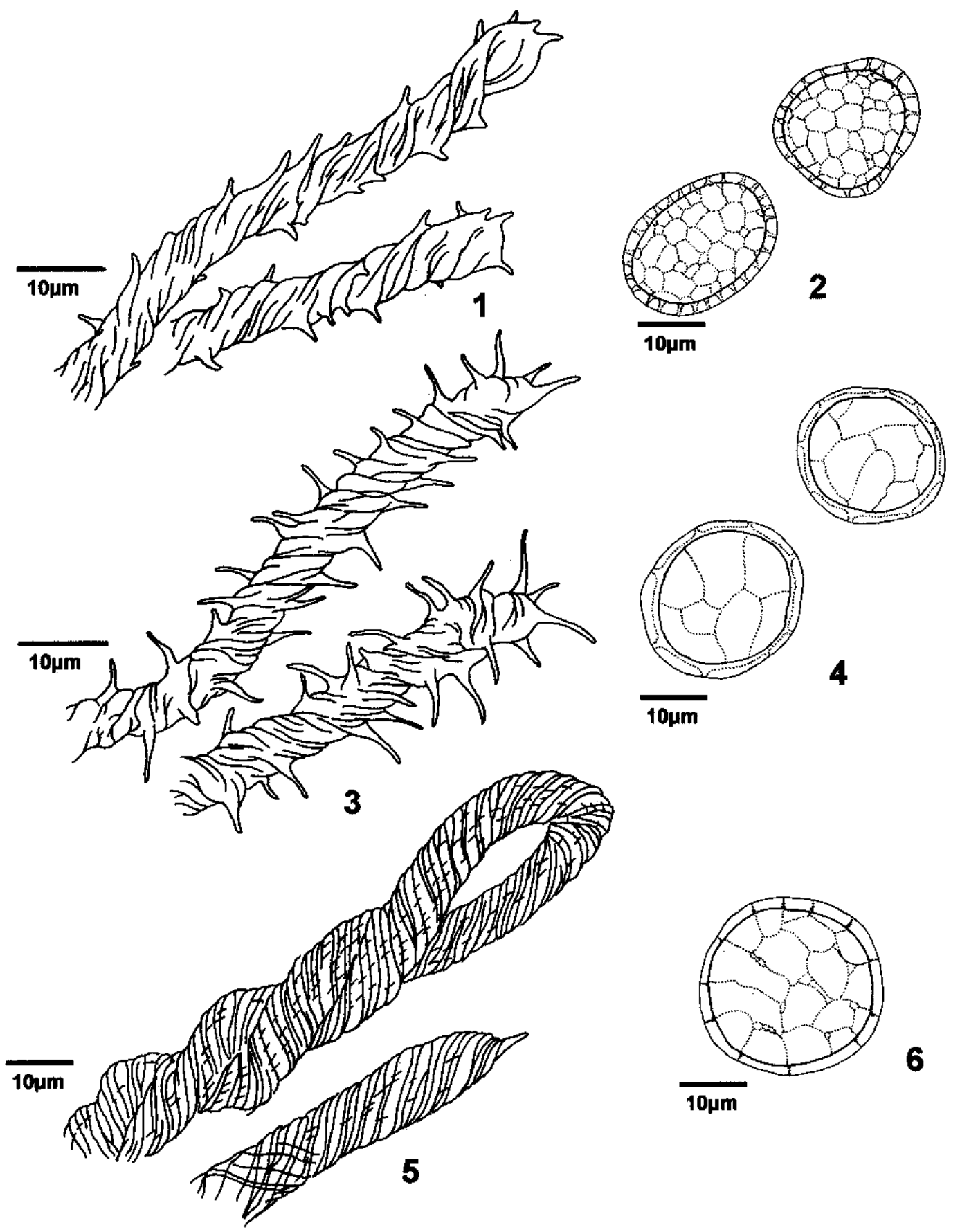

Figures 1-6. Microscopical details of the spores and capillitium of the three varieties of Hemitrichia serpula (Scop.) Rost., as seen under oil immersion objetive. 1. Capillitium of var. piauiensis (UFP16386), ornamented with short, aculeate, scattered spines; 2. Finely reticulate spores (UFP16386); 3. Capillitium of var. serpula (UFP1640), densely ornamented with strongly developed spines; 4. Large-reticulated spores of var. serpula (UFP1640); 5-6. Capillitium and spore of the var. tubiglabra (after Nannenga-Bremekamp \& Yamamoto 1990). 


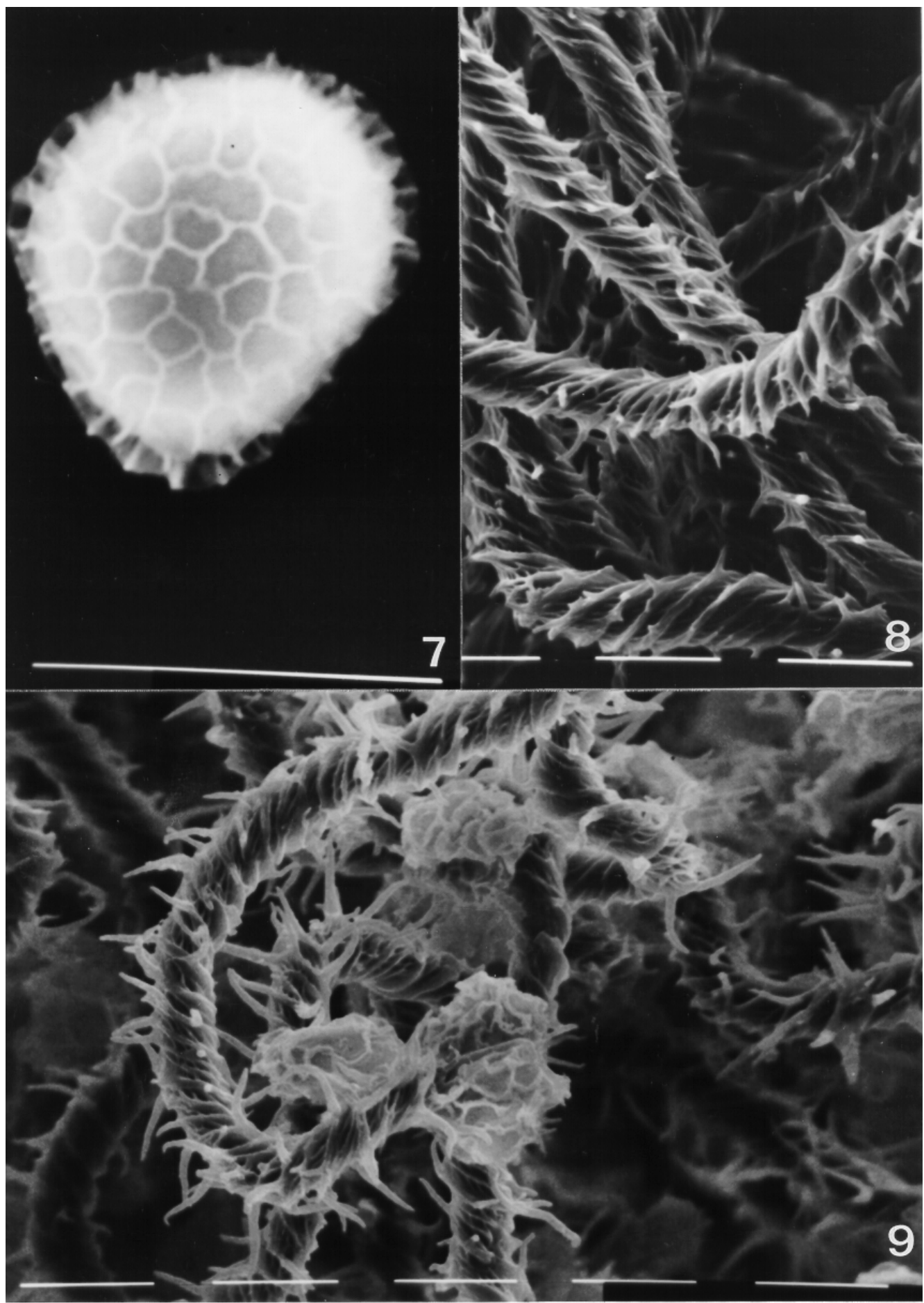

Figures 7-9. Microscopical details of the spores and capillitium of the varieties Hemitrichia var. serpula and $\boldsymbol{H}$. serpula var. piauiensis as seen with the scanning electron microscope. 7. Spore with small meshes, finely reticulate, of $\boldsymbol{H}$. serpula var. piauiensis (UFP16386) (barr $=10 \mu \mathrm{m})$; 8. Capillitium with short spines of $\boldsymbol{H}$. serpula var. piauiensis (UFP16386) $($ barr $=20 \mu \mathrm{m})$; 9. Capillitium with long spines and spores with large meshes, coarsely reticulate, of $\boldsymbol{H}$. serpula var. serpula $(\mathrm{UFP} 16404)$ (barr $=10 \mu \mathrm{m})$. 
those var. serpula by the fine reticulations in the wall, which are barely visible through the LM at low magnification; under the oil immersion objective the spore wall ornamentation is more clearly seen as verrucose or warty-reticulate (Fig. 2).

The spores and capillitia of the two varieties are still better distinguished by the SEM (Fig. 7-9). Figure 7 shows that the spore wall of var. piauiensis, which looks verrucose or wartyreticulate under the LM, is in reality bandedreticulate.

Key to the varieties of Hemitrichia serpula

1 Capillitium 4.5-6.0(-8.0) $\mu \mathrm{m}$ diam., spinulose

2. Spores $10.0-16.0 \mu \mathrm{m}$ diam., coarsely and irregularly reticulate, mesh $3.0-4.5 \mu \mathrm{m}$ large; capillitium with long, abundant spines H. serpula var. serpula

2. Spores $10.5-12.0(-13.8) \mu \mathrm{m}$ diam., finely and regularly reticulate, mesh $1.0-2.0 \mu \mathrm{m}$ large; capillitium with short, scattered spines ............. H. serpula var. piauiensis

1. Capillitium 8.0-9.0um diam., smooth; spores $12.0(-13.0) \mu \mathrm{m}$ diam., laxly reticulate

H. serpula var. tubiglabra

\section{Acknowledgements}

The authors are grateful to the following persons: Dr Williams Sanders, for kindly checking the English; MSc Fernando Mota Filho (UFPE), for the translation into Latin of the description of the new taxon. This research was supported in part by the Conselho Nacional de
Desenvolvimento Cientifico e TecnológicoCNPq (Proc.300626/79-7). The second author is indebted to the Coordenação de Aperfeiçoamento de Pessoal do Ensino Superior-CAPES and Fundação de Amparo à Ciência e Tecnologia-FACEPE (grant 537-203/96) for financial assistance.

\section{References}

Alves, M. H. \& Cavalcanti, L. H. 1996. Myxomycetes em palmeiras (Arecaceae). Acta Botanica Brasilica 10(1): 1-7 .

Farr, M. L. 1976. Myxomycetes. Flora Neotropica. Monograph 16. New York Botanical Garden, New York.

Martin, G. W. \& Alexopoulos, C. J. 1969. The Myxomycetes. University of Iowa Press, Iowa.

Martin, G. W.; Alexopoulos, C. J. \& Farr, M. L. 1983. The Genera of Myxomycetes. University of Iowa Press, Iowa.

Nannenga-Bremekamp, N. E. \& Yamamoto, Y. 1990. Two new species and a new variety of Myxomycetes from Nepal. Proceedings of the Koninklijke Nederlandese Akademie van Wetenschappen 93(3): 281-286.

Nelson, R. K.; Scheetz, R. W. \& Alexopoulos, C. J. 1982. Taxonomic studies in the Myxomycetes. V. Significance of peridial and the spore ornamentation in the genus Tubifera with a revised key to the species. Mycologia 74(4): 541-548.

Pôrto, K. C.; Cavalcanti, L. H. \& Correia, A. M. S. 1985. Myxomycetes em palmeiras. Pp. 181- 187. In: Anais do XXXIII Congresso Nacional de Botânica. EMBRAPA, Brasília.

Teixeira, A. R. 1971. Gêneros de Myxomycetes. Rickia supl. 4: 1-150.

Villaró, M. C. 1991. Myxomycetes de Cuba. Revista del Jardin Botánico Nacional 12: 127-131. 
